\title{
Lyrical contours of Doina from Oltenia. Characteristics and analysis
}

\author{
Gabriel ZAMFIR ${ }^{1}$
}

\begin{abstract}
In the opinion of musicologists, "doina" is one of the richest genres and closest to the soul of people, be it vocal or instrumental. Moreover, the "doina" is the one which, along with the carol, despite its uncertain origins, gives a particular note to the Romanian folklore in general. In order to be able to organize the musical material that the "doina" form inside them, it is necessary to refer to the "doina" types and their classification criteria, which is the main objective of this article.
\end{abstract}

Key-words: doina, Romanian folklore

\section{Introduction}

This article, the second one having as research topic the lyrical constitutive nuances of the doina, especially of the Oltenian doina, reveals the classification part based on various criteria, the specific aspects of the doina from Țara Loviștei, as well as the rhythmic-melodic analysis of the doina. These are added to the definition, origins, themes and musical characteristics of the Doina described in the first article with a similar subject.

\section{Classification criteria}

A wide range of criteria with distinct aspects are usually considered, these being (apart from the above-mentioned themes):

- source of playing;

- the diachronic (evolutionary) criterion - according to this criterion the doina can be old layer, archaic and new layer;

- the synchronic criterion (zonal spread) - according to this criterion, types of genus such as doina maramureşană (one of the oldest types), doina

\footnotetext{
${ }^{1}$ University of Craiova, gabriel.zamfir@habitatcraiova.ro
} 
gorjeană, doina muntenească, Transylvanian doinit song etc. may be mentioned.

Regarding the area spreading, we have to point out some aspects. The first one regards the changes made to the doina in the structural level, by continually updating its content and the influences of other genres (the song itself, in particular), which led to the emergence of intermediate types such as doinăbaladă, doina crystallized (strofică), doina-song, etc.

The second one looks at the evolution of doina's spread, which is influenced by the attitudes of communities to this genre. Doina continues to be present in areas such as northern Oltenia, Moldavia and Dobrogea, in Muntenia and some villages in northern Transylvania, and at the same time to be endangered or in the repertoire of musicians (in instrumental version), in many regiments of the country.

The diachronic criterion is intertwined with the synchronous one because of the archaic types which are maintained only in a few areas and not with the same frequency (Maramureş, Oaş, Năsăud, Bucovina, Subcarpathian Oltenia), later joined by more types (including in Transylvania, Oltenia, Muntenia and Moldova) and "love" types (in Muntenia, Dobrogea and southern Oltenia). We can identify them according to the sound material used, the ways of intermingling of some poetic-musical elements (interjections, refrains, syllables), according to the form of the recitatives and the architectural structures.

\section{Doina classification}

The most complex classification is according to the execution source that identifies the following types of doina:

a) Vocal Doina (encountered in most areas where the genus is preserved Maramureş, Oaş, Sălaj, Năsăud, Jara Bârsei, Jara Oltului, Sibiu, Oltenia, Muntenia, Moldova, Bucovina;

b) Instrumental Doina that can be:

- Pastoral or instrumental on itself (richly ornamented, with frequent apogiatrics, trills etc. that according to the technical possibilities of the instruments);

- of vocal origin (they are less frequent than the vocal ones) in all areas, including Banat; in Bihor doina is not attested; sometimes it is built on vocal doina motifs by instrumental adaptation while preserving the outline of the melodic lines, but some formulas are expanded through 
ample and repeated ornaments and others are concentrated by reducing the number of sounds in the recitative;

c) The vocal-instrumental doina - is performed simultaneously, monodic (heterophonic) by voice and by traditional instruments (voice-whistle); sometimes it is accompanied by a taraf (it is the case of "love" doina). The vocal-instrumental singing practiced in some areas (Voice - cetară in Maramureş, voice-whistle in Năsăud), creates many hetero-phonic effects.

\section{Relevant aspects of doina from Țara Loviștei}

Taking as a starting point these general data, we can focus our attention on highlighting the most interesting aspects specific to doina in the Land of Lovişte, as resulted from the materials collected and studied on field research. We also make assessments that refer to another important field within the doina, namely the melodics.

\subsection{Specific aspects of doina from Țara Loviștei}

Thus, there are three important types that can be included in the broad doina category:

- archaic. Reading in the „book of thought", as Constantin Brăiloiu puts it, places the evolutionary layers from archaic to classical and to "love", because all of them can all be regarded as traditional. The collections being, as mentioned, relatively late, the analytical judgments result from sensing the genres and from the melodico-rhythmic-archetectonic structures;

- classical. In classical styles, the definition of doina gains some more peculiar features, typical elements are more clearly outlined architectural and sonorously;

- of love: a relatively recent layer, emerged in the South of the country, is the "love" doina. Beyond the more or less erotic accents of the poetic text, musical deployments sometimes reserve the most complex connections, such as polychords.

The first is represented by what we call the vocal doina, which in the Oltenia area is the most common doina type on the territory of our country.

Mentioning for the beginning the characteristics referring to versification, we note that from the point of view of the syllable group, in the doina in the area mentioned, the metric pattern characteristic of the genus is generally the octosilabic, mostly in the acatalectic form. 


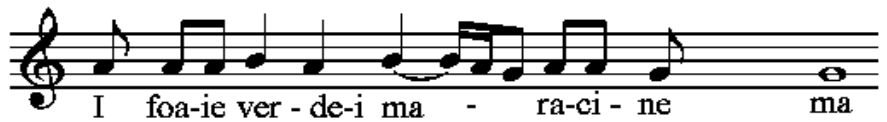

Fig. 1. Popular verse with acatalectic octosyllabic pattern

Sometimes we can also encounter the situation where the metric ocosilabic pattern appears in catalectic form.

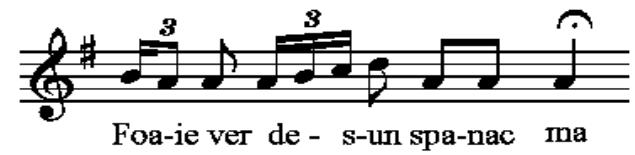

Fig. 2. Popular verse with catalectic octosyllabic pattern

In the case of the doina from Oltenia (and not only), the elements of versification used are:

- fill syllables: "i", "mă"

- apocopes: „blestema” , „c-o cruce” , „muarte-i” , „nu-i”

- regionalism: "fuoaie" "fuoc"

- other elements, an example of which is anadiplosis encountered in "Cântă cucul sus la munte".

Other elements encountered in aspects of versification are the chorus, which may be pseudo-chorus, a bisyllabic chorus, for example - „of, of" or a melodic recitative with the role of a chorus, and the strophe, characterised by mating rhyme, most of the time being successive.

\section{Ex: „Fuaie verde-i mărăcine, mă, \\ Dete frunza de arine, \\ Gata şade mărăcine \\ lacă primăvara-m vine..."}

\subsection{Rhythmic-melodic analysis of the doina}

The following considerations refer to another important field within the doina, namely melodic. Within this, we can note that the doina melody is syllabic and melismatic or built on melodic recitatives. 
In turn, the melody is individualized by several aspects such as the large ambitus (dominates the one in the perfect octave range), outlined contour, metric profile with tendencies in both possible directions - upward and downward (Cântă cucul sus la munte), and descending ascendant (Munte munte vârf înalt) or the ranges used, which in most cases assume the presence of the gradual gait (2M) or smaller jumps (3M, 3m or $4 p)$; less frequent jumps occur ( $5 p, 6 M, 9 m)$.

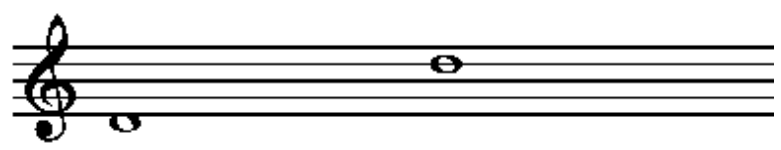

Fig.3. Ambitus: $8 p$

A particular component of the melody consists of cadences, rather complex and clearly defined, no matter what they are. The cadences on the final of the melodic strophes are usually made on the first step, very rarely on the second, by a semiparlando downward sliding, from the fundamental to the fifth. In vocal doina we have:

- Inner cadences on the 5th and 4th steps and the final on step II (Munte, munte, vârf înalt)

- Inner cadences on step I and III and final on Step II (Doină oltenească)

- Inner cadence on step I and final on step II.

- In these types of cadences, we note that there is a certain predilection for the use of the finale on the second step, and, in relation to this aspect, towards the achievement of the final frigic cadence in the second step.

The next parameter we submit to the analysis is the rhythm. Here we must remember the almost exclusive use of the rhythmic system parlando rubato; it allows the performer to behave freely by certain giusto-sibalic rules of framing, to prove his inventiveness and talent.

Some pertinent observations should be made regarding the rhythm, where it is possible to add elements related to the rhythmic formulas present in the structure of doina from Oltenia. These are quite varied and largely reflect the vocal character of those doina, while also highlighting the linkage with instrumental genres, so we will continue to show the most common rhythmic formulas encountered:

- pyric type:

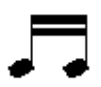


- trochee type:

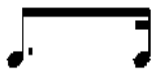

At a lower frequency, but quite common are:

- iambic:

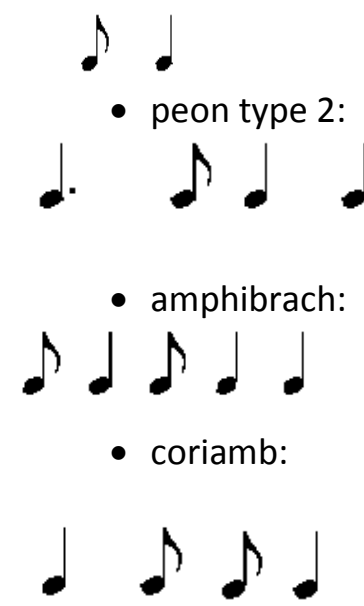

In any folklore genre (and not only), so in the doina structure, an important role is played by the sound system. The most important aspect of this parameter concerns the mode (the musical scale) in which doina is conceived; in connection to this element our research has led to two ideas. The first is that the analyzed examples have revealed a predominance of a particular sound system in which the doina are conceived, namely the Mixolidian mode (sometimes it appears with the third movable step in a minor configuration and with a frigic cadence).

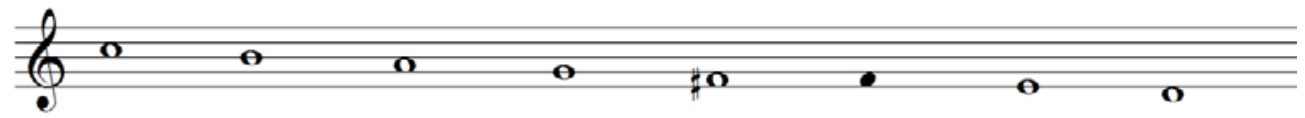

Fig. 4. Mixolidian with the third mobile stage

The second idea relates to a more particular detail: in the doina analyzed we were able to notice quite complex sound structures. A suggestive example is Doină oltenească where the first three phrases are constructed in the mixolidian mode on $\mathrm{G}$ that is based on step 4 of the anth- mountonic pentathion, then modulate to a minor pentacord with step IV altered suitor and frigic cadence in step II.

Also, in the parameter that concerns the sound system, we can remember that the doina from Vâlcea area has a melodic strophe made up of four to six 
melodic lines, and the architectural form (the strophe succession) uses the $A B$ scheme or A B chorus (binary type).

In the final analysis of the doina we will approach the problem of the creative processes through which the author, the interpreter ennobles the song of doina with the help of technical elements. Thus, we can encounter reason transmutation from one section to another (sometimes cadences are moving)

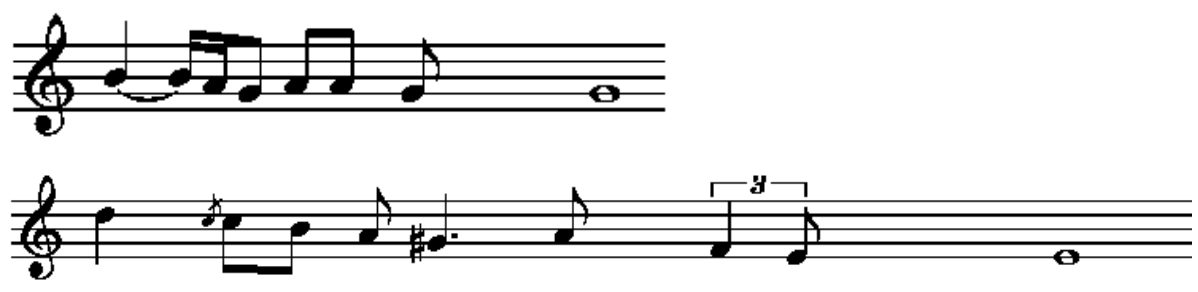

Fig.5. "Doina" from Oltenia
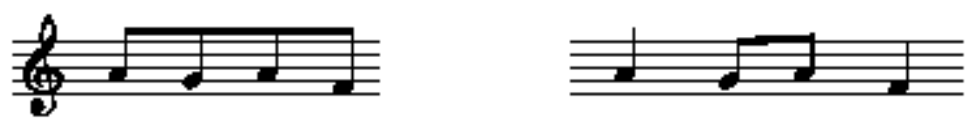

Fig.6. Repeating the cell by changing the focus

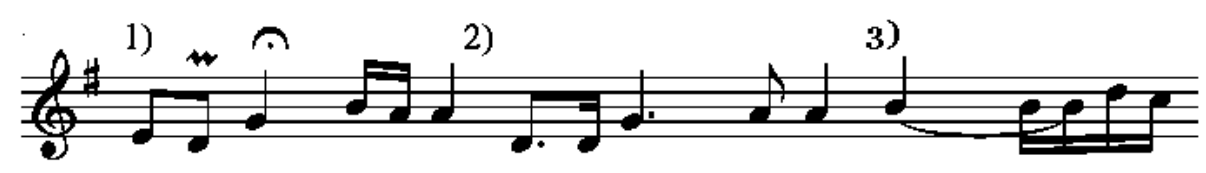

Fig.7. Interval-shift sequencing

or the use of the upward quart, characteristic of romanian doina, and of melisma (appoggiatura, mordente) etc.

Pointing out that the doina are very complex and quite varied, we can note that in Oltenia they do not have specific characteristics only in this area, but also have features encountered in the doina of Northern Transylvania.

In the Oltenia area, the instrumental doina is part of the pastoral repertoire, the most widespread occupation in the area being the grazing. These have some features common to vocal doina, but largely adapt to the features of the 
instrument to which they are played (the whistle). Thus, in the melodic paramether, we remember that the melody of instrumental doina is mainly built on the succession of melodic recitatives; at the same time, however, the song may include elements of the vocal doina or even of the dance songs (not often the performer tries in some moments of the Doina to prove his technical abilities).

Other aspects of the melodics of instrumental doina from Oltenia are related to melodic ambitus that can be unitary (the same throughout the doina) and reaches the small decimus, or specific to each of the sections, when the doina is completed with a dance.

Here, we can also mention that the instrumental doina has a concave contour with a pronounced downward trend and uses intervals that determine a whistle-specific melody ( $2 \mathrm{M})$ and third $(3 \mathrm{~m}$ and $3 \mathrm{M})$ jumps; the larger jumps (especially 4p) occur especially at the beginning of the doina.

Also included in the melodics are the cadences, which in the instrumental doina from Oltenia are determined by their formal structure. Thus, if the doina is not completed by dancing songs, the inner cadences are made on the first and fifth steps with the final on step VI. On the other hand, if the doina have a doina-dance structure, the cadences are on the fourth step with the finals on the Doina side, and on the third step with the finale on step I for the dancing songs included in the doina.

And in the realm of rhythm, we must emphasize the use of a system distinct from those encountered in the vocal doina, although it may be likened to parlando rubato. It is the free-improvisational system, one of the defining elements of the particular genus that includes doina; it gives the interpreter the opportunity to show him unrestrained and to demonstrate his ability to enrich the song of doina. Here we can note that the rhythmic formulas used are quite reduced because they represent the rhythmic pillars of improvisational elements. The most common formulas are:

- the pyrrhic:

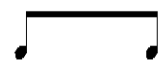

- dipiric:

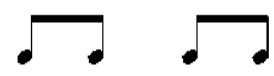

- diminished amphibrach:

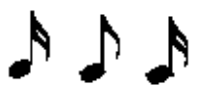


- diminished dactyl:

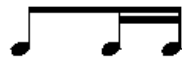

Besides these formulas, we can also find the compound ones that combine two (or more) simple formulas - a good example being the anapest + dactyl linked by syncope - which are meant to increase the difficulty of the song the interpreter sings.

Looking at the sound system, we found that the instrumental doina keeps the distinction between the two types of structures, so if we mention the musical scale in which the doina are played without dancing melodies, then that is, in particular, the mixolidian mode (usually on $D$ the 7th mobile step). For the more complex doina type, which includes a dancing song in addition to the doina, the soundtrack used is anhemitonic pentathony, in the fourth step on the D flat (specific doina in southern Transylvania) in the first part, and in step I flat (on C) in the dancing song.

We should emphasize that in the sound system the melodic strophe of the instrumental doina is in most of the collections composed of four or five melodic lines; in the case of doina filled with dancing songs, the latter are built on a bipartite pattern on Scheme A B. We also note that the type of the strophe can be based on the principle of repeated recitative, or it may determine a form of the $A B$ Avar type doina.

Last but not least, it is also worthwhile to review the most used creative methods encountered in the instrumental doina from Jara Loviştei. Thus, often the process of cell transmutation or reason from one section to another occurs,
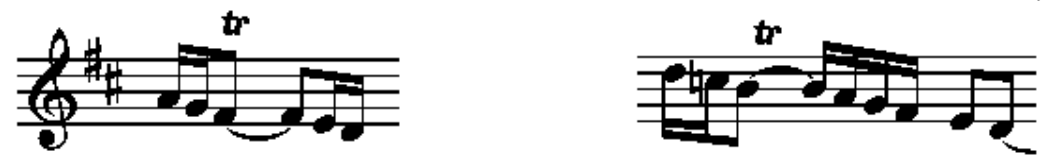

Fig. 8. Cell transmutation

or the process of repeating the cell or reason,

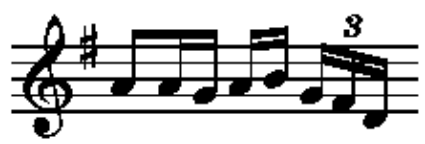

Fig.9. Repeating the cell

adding them to the ornamentation elements (tril, apogiature, mordent). All this contributes to the enrichment and creation of songs that the singer often sing for 
himself when going to the sheepfold with the sheep.

The literary aspect can be approached from another side in the "doinit" song from Jara Loviştei which is represented by the elements of versification, complex and varied:

•apocope: „mă-ntreabă"” ; „n-ai văzu'”; „n-auzi'”;

•filling syllables: „luațî”; , „altü"; , „măi”; ,"mă”;

-regionalisms: „ vria”; ,"niagră”; ,fietele”;

-interjections: ", of" (element taken from doina);

-anacruse: „,"; „ci" (specify all doina) ;.

•epiphora: „Chiar împărăteasă de-aş putea să fiu / Altuia mireasă nu vreau să fiu".

Following other aspects of the verse, I found the rhyme in the analyzed material, which is sufficient, sometimes presenting assonances (the element is also met in the actual modern song), and the chorus. In connection with this, we have to note that some songs have no chorus approaching the archaic song itself, while others have chorus, which can be of ornament type, „Leano, $f a$ "or thematic: "nană”, „of, nană"; ", bade dragă".

Woven throughout the theme of the proposed analysis, we have reached the aspects that concern the melodics of the "doinit" type song. Thus, we note that the melody can be syllabic or syllabic - melismatic and has a large ambitus that can be comprised between the entrances of the septime small and the big none (characteristic of the song).

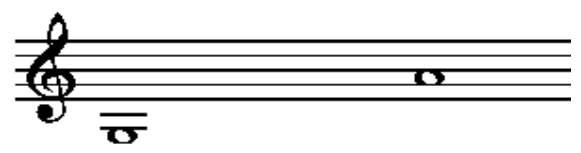

Fig.12. Large ambitus

Other elements that have attracted attention are the used musical ranges that are frequently encountered up to perfect quinte (very rarely we have musical ranges that go beyond sixth) and varied melodic cadences. They have different structures:

- inner cadences on steps V and I and final on step II;

- inner cadence in step I and final step II;

- inner cadences on step I and final step II, phrygic, with interpolation of sound A, support on the quarte, specific to ending formulas from doina and songs;

- Inner cadences on step III, I and V and final step I (Doric);

- Inner cadences on step I and IV, and final on step II.

Making it clear that the latest types of cadence are the most common, we can 
conclude that, in this respect, the "doinit" song takes over the characteristic of the doina, where the final is mostly placed on the second step, the dominant being phrygic type.

Following the framework of the analysis we will make some appreciations regarding the rhythm of the "doinit" song, the most interesting considering the predominance of the giusto-syllabic system with parlando interpretation, a defining feature of the "doinit" song that makes the synthesis between doina and song (in the case of modern song there is a synthesis between it and the archaic song). Other rhythmic systems rarely encountered in Oltenia "doinit" songs are the parlando rubato system (he suggests an even closer proximity to doina) and the aksak system, which has a presence that we can describe as sporadic.

The main rhythmic formulas used within the "doinit" song and which must be remembered because they have been subjected to the musical analysis of the chosen sample are: pyrrhic, diapiric, iambic, anapeste; less common are the formula trochee, sponde, diminished diapric, antispast.

A special place in the analysis I dedicated to the sound system from the song „doinit" from Țara Loviştei which is evidenced by a series of specific features (these are also found in other ethnographic areas).

The first is the preponderance of certain sound structures that underlie the collected songs. Thus, we can note that some of the most widespread systems are the mixolidian mode (on $D$, on $A$,), the ionian mode, phentathonic anhemitonic, state 4. Also, we can find cases where the "doinit" song involves the use of two sound systems, one for each section.

Another trait is in the composition of the melodic strophe, which is pretty elastic and varies from two to eight melodic lines. These are grouped into structures of various types, more often being: $A$ refr. $B$ (recitative formula); $A$ B (the most widespread form); A refr. B refr .; || A: ||: B: || and so on.

We cannot finish our analysis without finally recalling some of the most interesting creative methods used to enrich artistic songs. These processes are repeating,
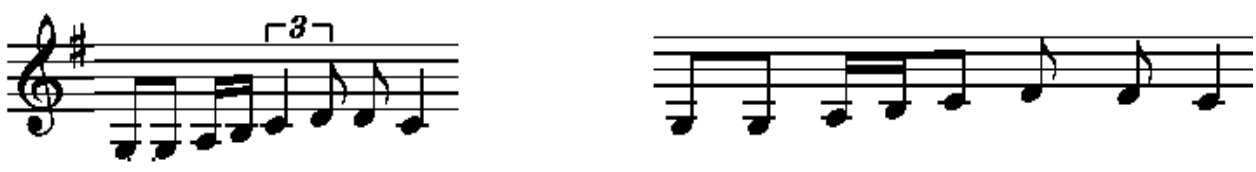

Fig.13. Repeating

the use of the motifs built on the question-answer principle, the use of the chorus as a constitutive element of the first section, which then maintains its function of refrain, etc. We also identify procedures such as recurrence, 


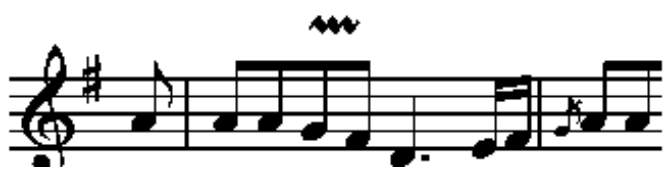

Fig.14. Recurrence

reversal,

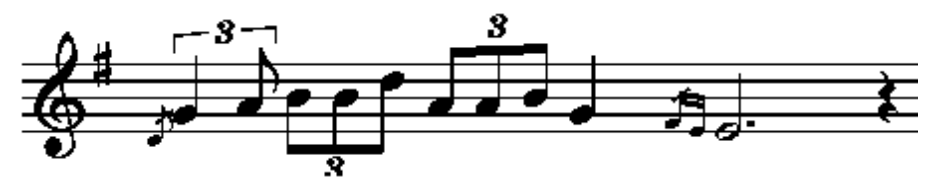

Fig.15. Reversal

or ornamentation elements (apogiatrics).

\section{Conclusion}

Closing these articles, we note that this genre is among the richest and closest to the soul of men; they express their joys and tribulations through a vocal or instrumental doina. Also, doina is the one that, along with the carol, despite the uncertain origins, gives a note of peculiarity to the Romanian folklore in general.

In 1940, Constantin Brăiloiu wrote: „Doina occupies the entire Carpathian chain and some restricted areas of infiltration beyond them. It is still at this moment the only lyrical melody known in a few isolated regions", (Brăiloiu 1940, 22) and Béla Bartók wrote: "The material gathered in the Old Kingdom proves that throughout Romania's pre-war war there is a certain melodic form, everywhere the same and of course very old, the so-called "cântec lung" (Bartók 1967, 122). Folklorist Ilarion Cocişiu concludes, speaking about the doina: "A Romanian spiritual unity has always existed ... and this unity is old as the people themselves" (Cocişiu 1944, 34).

\section{References}

Bartók, Bela. 1967. Rumänien Volksmusik. Vocal Melodies. New York.

Brăiloiu, Constantin. 1940. La musique populaire roumaine”, numero special: „La musique dans les pays latins" Fevrier-Mars, Paris.

Cocişiu, Ilarion. 1944. Folklore from Târnava Mare county. Sighişoara. 